\title{
Features of the organization of teaching for future physical education teachers in the People's Republic of China and the possibility of implementing an individual approach in their training: a review article
}

\author{
Xiaofei W. ${ }^{1}$, Korobeinik V.A. ${ }^{2}$, Kozina Z.L. ${ }^{3}$ \\ ${ }^{1}$ Lishui University, Lishui, Cina \\ ${ }^{2}$ Department of Cyclic Sports, H.S. Skovoroda Kharkiv National Pedagogical University, \\ Kharkiv, Ukraine \\ ${ }^{3}$ Department of Olympic and Professional Sports, Sports Games and Tourism, \\ H.S. Skovoroda Kharkiv National Pedagogical University, Kharkiv, Ukraine
}

DOI: https://doi.org/10.34142/HSR.2021.07.02.01

\section{How to Cite}

Xiaofei W, Korobeinik VA, Kozina ZL. Features of the organization of teaching for future physical education teachers in the People's Republic of China and the possibility of implementing an individual approach in their training: a review article. Health, Sport, Rehabilitation. 2021;7(2):8-17. https://doi.org/10.34142/HSR.2021.07.02.01

\begin{abstract}
Purpose: to determine the main directions of training of teachers of physical culture in the People's Republic of China according to the data of modern literature.

Material and methods. The analysis of literature sources was carried out by working with scientific works, which are presented in the databases "Web of Science", "Scopus", "Pub Med" and others. The search for literary sources was carried out by the keywords: "physical education teacher training", "physical education", "sports", "coach training". A total of 10157 works were found based on key words, of which 33 works were selected for literary review. The selection was carried out as follows: first, the topic of the article was analyzed, then, if the topic corresponded to the direction of our study, the annotation was analyzed. If the annotation corresponded to the direction of our research, the text of the article was analyzed. Also in the analysis of literature sources, preference was given to sources presented in the quartiles "Web of Science" and "Scopus" 1-3 level. In addition, articles on the training of physical education and sports professionals in China were analyzed separately. Of the 33 works presented in the literature review, 15 sources - research, 10 - review, 8 - randomized trials.

Results. In the People's Republic of China, the problem of individual approach is especially relevant in connection with national characteristics, traditions, which provide for the predominance of collective action in all types of work. In addition to basic sports, the training of future physical education teachers in the People's Republic of China should include in-depth study of the sport in which it could improve and be a high-level specialist.

Conclusions. Training of physical education teachers in the People's Republic of China should be based on modern concepts of individualization, which apply to all stages of training: from choosing a sport in which the student would like to improve and receive a specialty of physical education teacher with professional knowledge of a particular sport. physical education teachers in the study of the chosen sport.
\end{abstract}

Keywords: individual approach, teacher, physical culture, training 


\section{Анотація}

Ван Сяофей, Коробейнік В.А., Козіна Ж.Л. Особливості організації навчання майбутніх вчителів фізичної культури в Китайській Народній Республіці та можливість реалізації індивідуального підходу в їх підготовці: оглядова стаття.

Мета: визначити основні напрямки підготовки вчителів фізичної культури в Китайській Народній Республіці за даними сучасної літератури..

Матеріал і методи. Аналіз літературних джерел проводився шляхом роботи з науковими роботами, які представлені в базах "Web of Science», «Scopus», «Pub Med» ті інші. Пошук літературних джерел проводився за ключовими словами»: «підготовка вчителя фізичної культури», «фізична культура», «спорт», «підготовка тренера». Всього було знайдено за ключовими словами 10157 робіт, з яких було відібрано для літературного огляду 33 роботи. Відбір проводився таким чином: спочатку аналізувалася тема статті, потім, якщо тема відповідала спрямованості нашого дослідження, аналізувалася анотація. Якщо анотація відповідала спрямованості нашого дослідження, то аналізувався текст статті. Також при аналізі літературних джерел перевага віддавалася джерелам, представленим у квартілях «Web of Science» та «Scopus» 1-3 рівня. Крім того, окремо аналізувалися статті, що стосувалися підготовки фахівців 3 фізичного виховання і спорту в Китаї. 333 робіт, представлених в огляді літератури, 15 джерел дослідницького характеру, 10 - оглядового, 8 - рандомізовані дослідження.

Результати. У Китайській Народній Республіці проблема індивідуального підходу має особливу актуальність у зв'язку з національними особливостями, традиціями, які передбачають переважання колективних дій при всіх видах робіт. У підготовку майбутніх вчителів фізичної культури в Китайській Народній Республіці необхідно, крім базових видів спорту включити поглиблене вивчення виду спорту, в якому він міг би вдосконалюватися і бути фахівцем високого рівня.

Висновки. Підготовка вчителів фізичної культури в Китайській Народній Республіці повинна спиратися на сучасні концепції індивідуалізації, які стосуються всіх етапів підготовки: від вибору виду спорту, в якому студент хотів би вдосконалюватися і отримувати спеціальність вчителя фізичної культури з професійним володінням певним видом спорту, до врахування індивідуальних особливостей майбутніх вчителів фізичної культури при вивченні обраного виду спорту.

Ключові слова: індивідуальний підхід, вчитель, фізична культура, підготовка

\section{Аннотация}

Ван Сяофей, Коробейник В.А., Козина Ж.Л.. Особенности организации обучения будущих учителей физической культуры в Китайской народной республике и возможность реализации индивидуального подхода в их подготовке: обзорная статья

Цель: определить основные направления подготовки учителей физической культуры в Китайской народной республике по данным современной литературы.

Материал и методы. Анализ литературных источников проводился путем работы с научными работами, которые представлены в базах "Web of Science», "Scopus», «Pub Med» те другие. Поиск литературных источников проводился по ключевым словам»: «подготовка учителя физической культуры», «физическая культура», «спорт», «подготовка тренера». Всего было найдено по ключевыми словам 10157 работ, из которых были отобраны для литературного обзора 33 работы. Отбор проводился следующим образом: сначала анализировалась тема статьи, затем, если тема отвечала направленности нашего исследования, анализировалась аннотация. Если аннотация отвечала направленности нашего исследования, то анализировался текст статьи. Также при анализе литературных источников предпочтение отдавалось источникам, представленным в квартиль «Web of Science» и «Scopus» 1-3 уровня. Кроме того, отдельно анализировались статьи, касающиеся подготовки специалистов по физическому воспитанию и спорту в Китае. Из 33 работ, представленных в обзоре литературы, 15 источника - исследовательского характера, 10 - обзоры, 8 - рандомизированные исследования.

Результаты. В Китайской Народной Республике проблема индивидуального подхода имеет особую актуальность в связи с национальными особенностями, традициями, которые предусматривают преобладание коллективных действий при всех видах работ. В подготовку будущих учителей физической культуры в Китайской Народной Республике необходимо, кроме базовых видов спорта включить углубленное изучение вида спорта, в котором он мог бы совершенствоваться и быть специалистом высокого уровня.

Выводы. Подготовка учителей физической культуры в Китайской Народной Республике должна опираться на современные концепции индивидуализации, которые касаются всех этапов подготовки: от выбора вида спорта, в котором студент хотел бы совершенствоваться и получать специальность учителя физической культуры с профессиональным владением определенным видом спорта, с учетом индивидуальных особенностей будущих учителей физической культуры при изучении выбранного вида спорта.

Ключевые слова: индивидуальный подход, учитель, физическая культура, подготовка 


\section{Introduction}

In the last decade, China has set out to create a strong, competitive state in the world, which has led to increased interest in Western cultures and practices $[1,2]$. This requires the creation of conditions for the improvement of professionals from all fields, able to prove themselves in international economic and technological competition. Physical education is no exception, because physical education itself creates the basis for the formation of a physically healthy, intellectually and spiritually developed person. First of all, it concerns the training of specialists in physical education, which is an integral part of education.

At the present stage in the world there is a tendency to an individual approach to education [3, $4,5]$. This applies to all stages of the educational process: from kindergarten to university and postgraduate education. At the same time, with the increase of the educational level, the individualization of the learning process also increases. The field of physical culture and sports is no exception. In countries such as the United States, Europe and others, the trend towards a personal approach to physical education is realized in physical education at school by allowing students to choose sports to improve motor skills, health and psychological $[6,7,8,9]$.

This places certain demands on the training of specialists in physical education and sports to work as physical education teachers at school. The modern teacher of physical culture at school must have not only basic sports at the primary-secondary level, but also be a perfect specialist in a particular sport $[9,10]$. This is necessary to ensure a strategy of individual approach to the process of physical education of schoolchildren. In order for each student to be able to choose a sport for physical education, the school must have specialists in a large number of sports and physical activity.

The implementation of the individual approach consists in the following provisions: definition of the chosen sport in the early stages of learning [11, 12, 13, 14]; improvement in the chosen sport based on the individual characteristics of students - athletes.

In the People's Republic of China, the difficulties characteristic of all countries in the field of training specialists - future teachers of physical education, are added to the country-specific [1]. Physical education in the People's Republic of China has long been based on national traditions, and has focused on health promotion and training of servicemen [1, 15]. For this purpose, traditional Chinese systems were used: wu-shu, qigong and others, but not the sports for which competitions are held in the world, which is typical for Europe, USA, CIS countries and others (Andriamampianina P., Moussa AS, 2005). . Physical education in the People's Republic of China began to focus on the various sports for which competitions are held in the world, only the last 3-4 decades [1].

Therefore, on the one hand, physical education in the People's Republic of China has less experience in the implementation of sports that are used in competitions around the world, compared to Europe, the United States, the CIS and others. On the other hand, the introduction of sports in physical education is contrary to the cultural traditions of China and meets with some resistance from the population $[1,16]$.

Therefore, at the present stage, according to the direction of China's chosen direction of development, in the training of specialists in physical education and sports - future physical education teachers, there are several problems that need to be addressed. The first problem is the need for a harmonious combination of traditional Chinese practices in physical education with the implementation of a steamy approach focused on sports for which competitions are held in the world. The second problem is the need to combine the implementation of an individual approach, which is to improve in the chosen sport, with the study of basic types. The third problem is the need to take into account the individual characteristics of students when improving in the chosen sport.

Thus, at this stage it is necessary to develop an experimental training program for students future teachers of physical education, focused on an individual approach, which takes into account: 1 - a combination of Chinese traditions with current trends in physical education in the world; 2 - a combination of improvement in the chosen sport with the study of basic sports; 3 - reliance on individual characteristics of students with advanced nor in the chosen sport.

This determined the chosen direction of our research.

Purpose: to determine the main directions of individual approach to the training of physical education teachers according to modern literature. 


\section{Material and methods}

\section{Eligibility criteria}

The review included articles on the organization of the process of training physical culture teachers in the World and, in particular, in the People's Republic of China.

Articles were to be written in English and published in a peer-reviewed journal with the full version of the article available. All entries were allowed. Studies that were neither randomized studies nor reviews were excluded.

The review also included articles devoted to an individual approach to physical education of students and to the preparation of athletes.

\section{Sources of information and search strategy}

The analysis of literature sources was carried out by working with scientific works, which are presented in the databases "Webmof Science", "Scopus", "Pub Med" and others. The search for literary sources was carried out by the keywords ":" physical education teacher training "," physical education "," sports "," coach training ".

\section{Study selection}

The selection was carried out as follows: first, the topic of the article was analyzed, then, if the topic corresponded to the direction of our study, the annotation was analyzed. If the annotation corresponded to the direction of our study, the text of the article was analyzed. Also, in the analysis of literature sources, preference was given to sources presented in the quarters level 1-3 "Web of Science" and "Scopus". The first author (WX) selected articles to be included in the review. If any of the selection criteria were not met, the article was excluded from the systematic review. In case of doubt, the article was discussed with one of the co-authors (ZK) until a consensus was reached.

In addition, articles related to the training of specialists in physical education and sports in China were analyzed separately.

\section{Results}

A total of 10157 works were found by keywords, of which 33 works were selected for literary review. following.

Analysis of literature sources showed the

The study [1] examined the role of physical education teachers and related curricula in the emergence of specific concepts in physical education in Europe and the People's Republic of China. One of the key assumptions was that physical education teachers who work with a particular program will either support it or will doubt that physical education programs affect physical fitness and teaching methods.

Research [1] included a comparison of two very different and influential social models and academic systems. Comparisons were made between European and Chinese universities in terms of education, taking into account other comparative studies of higher education in the People's Republic of China, as well as research in higher education and teacher training in Europe [17, 18]. The work [1] is based on research conducted at European universities and at the Beijing University of Physical Education (People's Republic of China).

Because both Europe and the People's Republic of China have centralized education systems, both physical education universities can be considered representative of national teaching methods here and there. Teacher training is organized in almost the same way in all universities in Europe [1]. The same applies to the People's Republic of China, although some universities are quite autonomous [1, 19, 20, 21].

In Europe, various models of human modelling, reflecting changes due to technological progress, have influenced both the orientation and the content of exercise in the last century [1]. As a result, in Europe there are several approaches to the study of the theory of physical education: training in movement technique was based on a biomechanical model; regulation of loads (physiological pedagogy) was based on a bioenergetic model; The concept of how the human body is arranged in the application to the theory and practice of physical education, led to a three-dimensional concept of the human body: one dimension is a mechanical mode in which visible movements are studied, the other is an energy mode in which predominate physiological aspects, and thirdly, the neural mode in which the exchange and transmission of signals.

From a philosophical and psychological point of view, physical education was also influenced by Cartesian dualism, associationism, Gestalt theory, phenomenology, psychoanalysis, structuralism and systematism [22].

Analysis of the evolution of physical education shows that in Europe the emphasis is on sports [23]. Indeed, sports have long predominated in physical education. Although teachers have a place for creativity, different sports are a cultural landmark taught in schools and universities. However, the 
increasing dominance of sports practices in physical education has faced some opposition. Psychomotor skills, traditional local games, spontaneous classes, self-expression and free outdoor activities have been advanced in an attempt to balance the dominance of the sport. Currently, although sport continues to dominate in European physical education, these countercurrents have helped to increase diversity in the discipline of "Physical Culture" [23].

In terms of teacher training, European universities are relatively autonomous when it comes to determining the content of the curriculum. Pedagogical training covers three main subjects: theoretical sciences, pedagogy, didactics of physical activity and sports. Each subject affects the concept of learning and includes the conflict between "practitioners" and "theorists" (Andriamampianina P., Moussa A. S., 2005); between university teachers and high school teachers; between the scientific statements of universities and the commitment of teachers of physical education exclusively to practical training. Physical education curricula should be consistent with the research work and the practical experience of the teacher's physical education. European University Physical Education Courses (STAPS) reflect a desire to strengthen academic legitimacy at a time when universities are increasingly adapting their curricula to the requirements of practicing teachers [1].

In the People's Republic of China, physical education is determined by socio-political expectations and attitudes, not by abstract conflicts. There is the greatest conflict within the discipline of "Physical Culture" between the supporters of traditional Chinese practices and the founders of modern sports practices, which are usually more accessible to the general public and focused on integration with Europe [1].

Since the founding of the People's Republic of China, competitive sports have become an integral part of physical education. The government has taken steps to encourage the development of sports, both to improve health and to build national identity. Therefore, physical education, along with sports, is seen as a means of strengthening the relationship between man and the state. Thus, there is a close connection between the state and the school [1].

Chinese and traditional practices differ from Western sports in four main principles [15, 16]: 1 their main purpose - to improve health; 2 - in movements often there is an imitation of living beings; 3 - they embody philosophical concepts; 4 their development reflects the development of Chinese society as a whole. Moreover, they can be divided into different categories [1].

On the one hand, there are traditional health and fighting practices, such as wushu, taijiquan, qigong. On the other hand, there are entertaining, festive and popular practices, such as dragon boat races, dragon dances, kite launches, horse racing, work games, farm games and traditional games for minorities. To this list one could also add statesponsored practices, such as exercise programs broadcast on the radio or held during breaks, which are usually aimed at increasing production [1].

The development of physical education in the People's Republic of China was closely linked to military training and health activities until the end of the XIX century. The growing influence of the West has broken several age-old Chinese traditions. Since then, Western sports practices have become more and more popular and widespread. As a result, modern physical culture in the People's Republic of China is based on Western natural physical education under the influence of European and American theorists and teachers, such as Bazedov, Hutsmut, Gaulhofer, Eber, and Rousseau. The adoption of Western physical education is also an expression of the reaction against religious asceticism in favor of a "full" form of physical education, which allows everyone to find a "natural" movement [1].

This type of physical education has replaced military training, and its humanistic nature and values have led to one of the most profound transformations in Chinese physical education. The adoption of sports undermined Confucian traditions and marked a turning point in the development of physical education practices, although this phase was later followed by the rehabilitation of traditional practices. Currently, physical education in the People's Republic of China can be divided into three separate forms: health practices, military practices and Western sports practices. The emphasis is currently on sports practices [1].

With regard to teacher training, there is little evidence of internal contradictions, however, there is some tension in the People's Republic of China between "practical" and "academic" approaches. The modern system of education was developed in the late XIX century.

The system of educational colleges is very similar to the European system in that trainee teachers are hired after high school.

Both in Europe and in the People's Republic of China, the largest number of hours is devoted to practical subjects, albeit in different quantities (866 hours in Europe compared to 1596 hours in the People's Republic of China). In three years of study, Chinese students receive 2,640 hours of study, compared with 1,910 hours for European students. This difference in the total number of hours of study is equivalent to one European academic year [1]. 
Subjects for the study of foreign languages in the People's Republic of China and in Europe [1]: provisions:

Here it is necessary to consider four basic

1. The Chinese curriculum contains subjects related to the philosophy and politics of the modern People's Republic of China, which make up $8 \%$ of the curriculum, which is not included in the curriculum in Europe for the study of foreign languages;

2. Foreign languages are important $(10 \%$ of the curriculum) at Peking University, and in European universities they are almost absent (1\%) in the curriculum;

3. In both the People's Republic of China and Europe, biology is more important than the social sciences, although to varying degrees $(19 \%$ of the curriculum in Europe and $7 \%$ in the People's Republic of China), while the social sciences play a much smaller role among the curriculum components. in the People's Republic of China (2\%) compared to Europe (15\%);

4. Finally, school practice is a minimum of three years of basic teacher qualification in Europe (2\%) and is completely absent in the People's Republic of China [1].

With regard to the main sports activities offered in the first two years, the three key subjects in both cases are the same: athletics, gymnastics and team sports [1].

However, there is a wide range of activities in Europe. It would seem that due to the fact that curriculum developers prefer to focus on traditional sports, these basic classes are a mandatory requirement for students, beginners [1]

Thus, physical activity is at the heart of both curricula, reflecting the intention for future teachers to have theoretical and practical knowledge in the field of physical education. Of the three main elements of teacher training (physical activity, basic sciences and pedagogy) in the curriculum in Europe is dominated by physical activity. Although it can hardly be argued without a careful study of the content of the course, and teacher training - to promote the development of teaching skills [1].

Curricula are based on tools and methods specific to the professional activities of physical education teachers. At first glance, it seems that both curricula are based on a pragmatic approach with an emphasis on physical education and their educational programs. In the Chinese curriculum, research seems to be an additional rather than a major subject. But both in the People's Republic of China and in Europe, only a small part of the training is devoted to professional practice. Curricula offer training for professional purposes, but without practical teaching experience [1].

Rating of which items [1].

Europe:

1. Physical activity and sports

2. Biological sciences

3. Social sciences

4. Research methodology

5. Another

6. Practically at school

7. Written and oral self-expression

8. Computer science

9. Foreign languages

10. Legal / institutional framework

People's Republic of China:

1. Physical activity and sports

2. Foreign languages

3. Philosophy and politics

4. Biological sciences

5. Another

6. Informatics

7. Research methodology

8. Humanities

9. Written and oral language

10. Legal / institutional framework

Subjects that are not directly related to the field of physical education: foreign language, sightseeing and modern history of the People's Republic of China. The relationship between politics and education remains strong, both in form and content, but it is currently designed to reflect an "open door policy." Judging by the curriculum, a Chinese physical education teacher must be an expert in physical activity with extensive knowledge of Chinese philosophy and political history; he also has everything he needs to participate in international information exchanges due to his linguistic and computer skills [1].

The curriculum for physical education in Europe is mainly characterized by the fact that the emphasis is on scientific disciplines (which is more than a third of the curriculum) [1, 24, 25, 26]. Many authors $[27,28]$ point to the need to improve the quality of training of future professionals in the field of physical culture and sports, among which a special place is occupied by future physical education teachers.

\section{Discussion}

The problem of modern physical education at all stages of the educational process is that there is a gap in the needs of society in providing appropriate means and forms of physical activity and real human 
resources. In the training of future teachers of physical culture, insufficient attention is paid to improvement in the chosen sport, as well as - the development of modern forms and means of physical education and physical activity. In modern society it is necessary to implement an individual approach to the teaching of physical culture, which would take into account the benefits of choosing the type of physical activity of each person, and especially schoolchildren and students.

A specialist in the field of physical education must have both basic theoretical and motor training, and have a perfect command of at least one type of motor activity (sport). In this case, he will be able to ensure the implementation of an individual approach to at least one parameter - the choice of sport by students. In addition, he must be able to think creatively for the selection of means and methods of physical education depending on the level of training and individual characteristics of students. Therefore, there is a problem: a graduate of a higher education institution can not take an individual approach to physical education due to lack of knowledge about a particular sport, and the student can not take an individual approach due to lack of basic theoretical and practical knowledge [29, 30].

The root of the solution to the problem of individual approach in physical culture and sports lies in the training of specialists in the field of physical education and sports. This is especially true for the training of physical education teachers. But how can a graduate of a higher educational institution implement an individual approach in the physical education of students, because the training of future physical education teachers does not implement an individual approach?

The lack of a solution to the problem of individual approach in the training of future physical education teachers leads to a decrease in students' motivation to engage in physical education, which leads to lower quality of physical education in general and increased health problems. Therefore, solving the problem of individual needs in physical education is in the implementation of an individual approach in the training of future teachers of physical education.

In the People's Republic of China, the problem of individual approach is especially relevant in connection with national characteristics, traditions, which provide for the predominance of collective action in all types of work. In addition, in the People's Republic of China there is resistance from many organizations and professionals to introduce in physical education sports for which competitions are held instead of traditional Chinese health and combat $[31,32,33]$.
In addition to basic sports, the training of future physical education teachers in the People's Republic of China should include in-depth study of the sport in which he could improve and be a highlevel specialist. Training of physical education teachers in the People's Republic of China should be based on modern concepts of individualization, which apply to all stages of training: from choosing a sport in which the student would like to improve and receive a specialty of physical education teacher with professional knowledge of a particular sport. physical education teachers at studying the chosen sport.

In modern society it is necessary to implement an individual approach to the teaching of physical culture, which would take into account the benefits of choosing the type of physical activity of each person, and especially - schoolchildren and students. A specialist in the field of physical education must have both basic theoretical and motor training, and have a perfect command of at least one type of motor activity (sport).

Chinese traditional practices differ from Western sports in four main principles [15]: 1 - their main goal is to improve health; 2 - in movements often there is an imitation of living beings; 3 - they embody philosophical concepts; 4 - their development reflects the development of Chinese society as a whole. Moreover, they can be divided into different categories [1].

On the one hand, there are traditional health and fighting practices, such as wushu, taijiquan, qigong. On the other hand, there are entertaining, festive and popular practices, such as dragon boat races, dragon dances, kite launches, horse racing, work games, farm games and traditional games for minorities. To this list one could also add statesponsored practices, such as exercise programs broadcast on the radio or held during breaks, which are usually aimed at increasing production [1].

The development of physical education in the People's Republic of China was closely linked to military training and health activities until the end of the XIX century. The growing influence of the West has broken several age-old traditions of China [3, 4, 5]. Since then, Western sports practices have become more and more popular and widespread. As a result, modern physical culture in the People's Republic of China is based on Western natural physical education under the influence of European and American theorists and teachers such as Bazedov, Hutsmut, Gaulhofer, Eber, and Rousseau. The adoption of Western physical education is also an expression of the reaction against religious asceticism in favor of a "full" form of physical education, which allows everyone to find a "natural" movement [1]. 
This type of physical education has replaced military training, and its humanistic nature and values have led to one of the most profound transformations in Chinese physical education [15]. The adoption of sports undermined Confucian traditions and marked a turning point in the development of physical education practices, although this phase was later followed by the rehabilitation of traditional practices. Currently, physical education in the People's Republic of China can be divided into three separate forms: health practices, military practices and Western sports practices. The emphasis is currently on sports practices [1].

With regard to teacher training, there is little evidence of internal contradictions, however, there is some tension in the People's Republic of China between "practical" and "academic" approaches. The modern system of education was developed in the late XIX century.

The system of educational colleges is very similar to the European system in that trainee teachers are hired after high school.

\section{Conclusions}

1. Theoretical generalization of literary sources has shown that in modern society requires the implementation of an individual approach to teaching physical education, which would take into account the benefits of choosing the type of motor activity of each person, and especially - schoolchildren and students. A specialist in the field of physical education must have both basic theoretical and motor training, and have a perfect command of at least one type of motor activity (sport).
In the People's Republic of China, the problem of individual approach is especially relevant in connection with national characteristics, traditions, which provide for the predominance of collective action in all types of work. In addition, in the People's Republic of China,there is resistance from many organizations and professionals to introduce sports in physical education, for which competitions are held instead of traditional Chinese health and combat systems.

3. In addition to basic sports, the training of future physical education teachers in the People's Republic of China should include in-depth study of a specific sport in which he could improve and be a high-level specialist. Training of physical education teachers in the People's Republic of China should be based on modern concepts of individualization, which apply to all stages of training: from choosing a sport in which the student would like to improve and receive a specialty of physical education teacher with professional knowledge of a particular sport. physical education teachers in the study of the chosen sport.

\section{Acknowledgments}

The study was conducted according to: research work on the topic of the Department of Olympic and Professional Sports, Sports Games and Tourism of H.S. Skovoroda Kharkiv National Pedagogical University for 2021-2026: "Development and substantiation of technologies for health promotion and harmonious development of people of different ages and social groups" (№ state registration: 0121U110053).

\section{Conflict of interest}

The authors declare that there is no conflict of interest.

\section{References}

1. Andriamampianina P, Moussa AS. Pierre andriamampianina and azzedine si moussa. the training of physical-education teachers in france and china: a comparative analysis of curricula and attitudes. International Review of Education. 2005;51(1):23-34. DOI 10.1007/s11159005-0588-7

2. Meng X, Horrell A, McMillan P, Chai G. 'Health First' and curriculum reform in China: The experiences of physical education teachers in one city. European Physical Education Review. 2020:218. DOI: $10.1177 / 1356336 X 20977886$

3. Liu DD, Li RW. Training of Physical Education
Teachers for Equal Access to Education. 2011.

4. Liu DD, Li RW. Training of Physical Education Teachers for Equal Access to Education. In M. Ma (Ed.), 2011 International Conference of Environmental Science and Engineering. 2012;(12):1269-1273.

5. Liu K. The Requirements of Modern Sports Training to the Quality of College Physical Education Teachers. Icmibi International Conference on Applied Social Science and Business (Icmibi-Assb 2016). 2016;65:113-115.

6. Apple MW. Democratic education in neoliberal and neoconservative times. International Studies in Sociology of Education. 2011;21(1): 21-31.

7. Bowe R, Ball SJ and Gold A. The policy process and the processes of policy. In: Ahier J, Cosin B and 
Hales M (eds) Diversity and Change: Education, Policy and Selection. London: Routledge. 1993:273278.

8. Burdett N, O'Donnell S. Lost in translation? The challenges of educational policy borrowing. Educational Research. 2016;58(2): 113-120.

9. Cale L, Harris J and Chen MH. Monitoring health, activity and fitness in physical education: Its current and future state of health. Sport, Education and Society. 2014;19(4):376-397.

10. Cale L and Harris J. 'Every child (of every size) matters' in physical education! Physical education's role in childhood obesity. Sport, Education and Society. 2013;18(4): 433-452.

11. Kozina ZhL, Cieslicka M, Prusik K, Muszkieta R, Sobko IN, Ryepko OA, Bazilyuk TA, Polishchuk SB, Osiptsov AV, Korol SA. Algorithm of athletes' fitness structure individual features' determination with the help of multidimensional analysis (on example of basketball). Physical education of students. $\quad 2017 ; 21(5)$ : 225-238 http://dx.doi.org/10.15561/20755279.2017.0505

12. Kozina $\mathrm{ZhL}$, Cieślicka M. Theoretical concept of individualization in sport. Poznań :Ośrodek Rekreacji, Sportu i Edukacji. 2018. 243p.

13. Kozina ZL, Krzysztof P, Katarzyna P. The concept of individual approach in sport. Pedagogics Psychology Medical-Biological Problems of Physical Training and Sports. 2015;19(3):28-37. doi:10.15561/18189172.2015.0305

14. Kozina ZL, Ol'khovyj O M, Temchenko VA. Influence of information technologies on technical fitness of students in sport-oriented physical education. Physical Education of Students. 2016;20(1):21-28. doi: $10.15561 / 20755279.2016 .0103$

15. Ward P., He Y., Wang X., Weidong Li. Chinese Secondary Physical Education Teachers' Depth of Specialized Content Knowledge in Soccer. Journal of Teaching in Physical Education. 2018;37:101112. https://doi.org/10.1123/itpe.2017-0092

16. Ward P, Tsuda E, Dervent F, Devrilmez E. Differences in the content knowledge of those taught to teach and those taught to play. Journal of Teaching in Physical Education. 2018:35. doi:10.1123/jtpe.2016-0196

17. Herold F. 'There is new wording, but there is no real change in what we deliver': Implementing the new national curriculum for physical education in England. European Physical Education Review. 2020. DOI: $10.1177 / 1356336 X 19892649$.

18. Song L, Chen J. University students' conceptions of an excellent physical education teacher in China. European Physical Education Review. 2012;19(1):110-126.

19. Li SG, Chen QH, Zhao HE, et al. Cultivation of newstyle physical education teachers under the background of the 'Health in China' strategy. Tiyu Xuekan. 2019;26(3):96-100.

20. Zhao WL. Epistemological flashpoint in China's classroom reform: (How) can a 'Confucian doafterme pedagogy' cultivate critical thinking? Journal of Curriculum Studies. 2019;52(1):101-117.

21. Yin X, Buck GA. There is another choice: An exploration of integrating formative assessment in a Chinese high school chemistry classroom through collaborative action research. Cultural Studies of Science Education. 2015;10(3):753-762.

22. Bayer C. Approches actuelles d'une e'piste'mologie des activite's physiques et sportives. Paris: L'Harmattan. 1999.

23. Andrieu G. Enjeux et de'bats en E.P. Une histoire contemporaine. Paris: Actio. 1992.

24. Chłon'-Domin'czak A. Changes in the education system in Poland, ESPN Flesh Report 2017/38. European Social Policy Network, European Commission. 2017. ec.europa.eu (01.02.2018).

25. Czarniecka R. Kształcenie nauczycieli wychowania fizycznego - potrzeba rzeczywistos'c ' [Educating PE Teachers - Needs and Reality]. Wychowanie Fizyczne I Zdrowotne. 2011;1:9-12.

26. Gawlik K, Zwierzchowska A. For motion of motor coordination abilities in boys with visual impairment - pedagogical experiment. Physiotherapy. 2011;19 (2):21-27.

27. Eisner EW. Reimagining Schools: The Selected Works of Elliot W. Eisner. Oxon: Routledge. 2005.

28. Fitzpatrick K. Burrows L. Critical health education in Aotearoa New Zealand. Sport, Education and Society. 2017;22(5):552-568.

29. Fullan M. The New Meaning of Educational Change. New York: Teachers College Press. 2007.

30. Haddad C. Innovative Practices in Physical Education and Sports in Asia. Bangkok, Thailand: UNESCO Asia and Pacific Regional Bureau for Education. Harris J (2009) Health-related exercise and physical education. In: Bailey R and Kirk D (eds) The Routledge Physical Education Reader. London: Routledge. 2008;83-102.

31. Li SG, Chen QH, Zhao HE, et al. Cultivation of newstyle physical education teachers under the background of the 'Health in China' strategy. Tiyu Xuekan. 2019;26(3):96-100.

32. Liu E, Liu C, Wang J. Pre-service teacher preparation in China: Challenges and promises. Journal of Science Teacher Education. 2015;26:29-44. doi:10.1007/s10972-014-9404-1

33. Seah WT. Ten years of curriculum reform in China: A soft knowledge perspective. In: Ryan J (ed) Education Reform in China: Changing Concepts, Contexts and Practices. Oxford: Routledge. 2011. 


\section{Information about authors}

\section{Xiaofei W.}

v.korobeynik71@gmail.com

Lishui University

Lishui, Zhejiang, China

\section{Korobeinik V.A.}

v.korobeynik71@gmail.com

https://orcid.org/0000-0001-6030-1305

H.S. Skovoroda Kharkiv National Pedagogical University

Altshevskih str. 29, Kharkiv, 61002, Ukraine

\section{Kozina Zh. L.}

http://orcid.org/0000-0001-5588-4825

zhanneta.kozina@gmail.com

H.S. Skovoroda Kharkiv National Pedagogical University

Altshevskih str. 29, Kharkiv, 61002, Ukraine

\section{Інформація про авторів}

\section{Сяофей $\mathrm{B}$.}

v.korobeynik71@gmail.com

Лішуйський університет

Лишуй, Чжецзян, $\underline{\text { Китай }}$

\section{Коробейнік В.А.}

v.korobeynik71@gmail.com https://orcid.org/0000-0001-6030-1305

Харківський національний педагогічний університет імені Г.С. Сковороди вул. Алчевських, 29, Харків, 61002, Україна

\section{Козіна Ж.Л.}

http://orcid.org/0000-0001-5588-4825

zhanneta.kozina@gmail.com

Харківський національний педагогічний університет імені Г.С. Сковороди вул.Алчевських 29, Харків, 61002, Україна

\section{Информация об авторах}

\section{Сяофей В.}

v.korobeynik71@gmail.com

Лішуйський університет

Лишуй, Чжэцзян, Китай

\section{Коробейник В.А.}

v.korobeynik71@gmail.com

https://orcid.org/0000-0001-6030-1305

Харьковский национальный педагогический университет имени Г.С. Сковороды; ул.Алчевских 29, Харьков, 61002, Украина

\section{Козина Ж.Л.}

http://orcid.org/0000-0001-5588-4825

zhanneta.kozina@gmail.com

Харьковский национальный педагогический университет имени Г.С. Сковороды; ул.Алчевских 29, Харьков, 61002, Украина

This work is licensed under a Creative Commons Attribution 4.0 International License (CC BY 4.0) 